\title{
Trophic state, phytoplankton assemblages and limnological diagnosis of the Castanháo Reservoir, CE, Brazil
}

\author{
Estado trófico, assembléias fitoplanctônicas e diagnóstico \\ limnológico do açude Castanhão, CE, Brasil
}

Mauricio Mussi Molisani ${ }^{1}$, Hortência de Sousa Barroso ${ }^{2}$, Helena Becker ${ }^{3}$, Maria Odete Parente Moreira², Carlos Alberto Grossi Hijo ${ }^{2}$, Thiago Maia do Monte ${ }^{4}$, George Harrison Vasconcellos ${ }^{4}$

${ }^{1}$ Núcleo em Ecologia e Desenvolvimento Sócio-Ambiental de Macaé - NUPEM, Universidade Federal do Rio de Janeiro - UFRJ, CEP 27971-550, Macaé, RJ, Brazil e-mail: molisanimm@yahoo.com.br

${ }^{2}$ Laboratório de Ciências do Mar - LABOMAR, Instituto de Ciências do Mar, Universidade Federal do Ceará - UFC, CEP 60165-018, Fortaleza, CE, Brazil e-mail: hortenciasb@yahoo.com.br, mariaodetepm@yahoo.com, grossihijo@yahoo.com.br

\author{
${ }^{3}$ Departamento de Química Analítica e Físico-Química, \\ Universidade Federal do Ceará - UFC, CEP 60455-760, Fortaleza, CE, Brazil \\ e-mail: becker@ufc.br
${ }^{4}$ Graduação em Engenharia de Pesca, Universidade Federal do Ceará - UFC, CEP 60455-760, Fortaleza, CE, Brazil e-mail: thiagotbn@yahoo.com.br, george_relson@yahoo.com.br

\begin{abstract}
Aim: The aim of this work is to diagnose the limnological conditions of the Castanhão Reservoir which is the largest and most important reservoir in the State of Ceará. This diagnosis is focused on physical-chemical variables, trophic state indices, and phytoplankton assemblages; Methods: Water samples were collected during six occasions from November/06 to July/07 from surface and bottom of the water column at three sites across the reservoir aiming to characterize physical-chemical (depth, transparency, suspended matter, temperature, dissolved oxygen, $\mathrm{pH}$, redox potential, dissolved silicon, nitrogen and phosphorous) and biological (Chlorophyll- $a$, phytoplankton assemblages and total density) variables; Results: The trophic state index variables obtained for the reservoir showed Secchi disk depth ranging from 0.65 to $2.4 \mathrm{~m}$, Chlorophyll- $a$ from 0.71 to $15 \mu \mathrm{g} . \mathrm{L}^{-1}$, total phosphorous from 11 to $369 \mu \mathrm{g} . \mathrm{L}^{-1}$ and soluble reactive phosphorous from 9.0 to $236 \mu \mathrm{g} . \mathrm{L}^{-1}$. The results characterized a riverine-lacustrine transition area with low depth, transparency, dissolved oxygen with one anoxic event, and high values of suspended matter, total phosphorous and ammonium. The reduced light availability is probably the main factor inducing the low values for total phytoplankton density and Chlorophyll- $a$. The predominant class of phytoplankton was Bacillariophyceae with main species Aulacoseira distans var. distans as functional assemblage C. Typical lacustrine portion of the reservoir has higher depth and transparency than inlet reservoir what probably explains the higher total phytoplankton density. Cyanophyceae was the predominante phytoplankton class with main species Cylindrospermopsis raciborski as functional assemblage Sn. The phytoplankton assemblages in the Castanhão Reservoir were typical for mesotrophic/eutrophic aquatic environments confirming the trophic state of the reservoir; Conclusion: After five years completely flooded, the Castanhão Reservoir might be considered a mesotrophic, although depletion of dissolved oxygen and presence of a potentially toxic phytoplankton species (C. raciborskii) suggests the necessity of reservoir management focused on anthropogenic nutrient emission control and maintenance of natural ecological succession of the reservoir.
\end{abstract}

Keywords: trophic state, phytoplankton assemblages, reservoir, semi-arid, State of Ceará. 
Resumo: Objetivo: $\mathrm{O}$ objetivo do presente estudo é realizar um diagnóstico das condiçóes limnológicas do açude Castanhão que é o maior e mais importante reservatório do Estado do Ceará. Este diagnóstico inclui a determinação de variáveis físico-químicas, estado trófico e assembléias fitoplanctônicas do açude; Métodos: Amostras de água foram coletadas durante seis ocasiōes durante novembro/06 e Julho/07 na superfície e fundo da coluna d'água e três porçóes do açude visando caracterizar parâmetros físico-químicos (profundidade, transparência, material particulado em suspensão, temperatura, oxigênio dissolvido, $\mathrm{pH}$, potencial redox, condutividade, sílica dissolvida, nitrogênio e fósforo) e biológicos (Clorofila- $a$, identificação e contagem de organismos fitoplanctônicos); Resultados: As variáveis analisadas para determinação do estado trófico do açude indicaram valores de profundidade de Secchi variando entre 0.65 e $2.4 \mathrm{~m}$, Clorofila- $a$ entre 0.71 e $15 \mu \mathrm{g} . \mathrm{L}^{-1}$, fósforo total entre 11 e $369 \mu \mathrm{g} . \mathrm{L}^{-1}$, fósforo solúvel reativo entre 9.0 e $236 \mu \mathrm{g} \cdot \mathrm{L}^{-1}$. Todas as variáveis analisadas pelo presente estudo caracterizaram uma área de transição entre a porção fluvial e lacustre com menores profundidades, transparência e oxigênio dissolvido com um evento de anoxia, maiores valores de material particulado em suspensão, fósforo total e amônia. A limitação de incidência luminosa é o principal fator que induz a reduzida produção fitoplanctônica, representada inclusive pelos reduzidos valores de clorofila $a$. A classe fitoplanctônica predominante nesta porção foi Bacillariophyceae representada principalmente pela espécie Aulacoseira distans var. distans, assembléia funcional C. A porção lacustre apresentou maior profundidade e transparência que induz a maior produção fitoplanctônica. Nesta porçáo do açude a classe fitoplanctônica predominante foi a Cyanophyceae com destaque para a espécie Cylindrospermopsis raciborskii, assembléia funcional $\mathrm{Sn}$, que configurou entre as mais abundantes. As principais assembléias fitoplanctônicas observadas são típicas de ambientes aquáticos mesotróficos/eutróficos corroborando as análises sobre o atual estado trófico do açude; Conclusáo: Após cinco anos da completa inundação, o açude Castanhão pode ser considerado mesotrófico, embora eventos de anoxia e a presença da espécie fitoplanctônica potencialmente tóxica $C$. raciborskii indiquem a necessidade de um manejo adequado visando o controle da emissão de nutrientes por atividades antrópicas e a manutenção da sucessão ecológica natural deste açude.

Palavras-chave: estado trófico, assembléias fitoplanctônicas, açude, semi-árido, Estado do Ceará.

\section{Introduction}

Trophic state, phytoplankton assemblages, and physical-chemical variables are important aspects of lake/reservoir survey usable to establish the freshwater's conditions (Carlson, 1977; Esteves, 1998; Reynolds et al., 2002). This practical hierarchy classification and limnological diagnosis usually indicates a "snapshot picture" of the reservoir conditions, although the results should also be taken as a transient momentum of the natural reservoir succession (Kimmel and Groeger, 1986; Figueiredo and Bianchini Jr., 2008).

During the ontological process, reservoirs commonly become more productive soon after reservoir filling, although ontogeny does not always lead to reservoir eutrophication (Kimmel and Groeger, 1986; Hall et al., 1999). After the upsurge period, the reservoir then declines if external nutrient loads remain constant during the reservoir aging. However, multiple reservoir uses and watershed-based human activities bring changes on nutrient inputs that are probably the major reason to induce modification on the reservoir's trophic status, phytoplankton assemblages and physical-chemical conditions. According to the magnitude and interval of the stressor, continuous deviation from natural succession might reduce the reservoir recovery capacity and induce alternative states that decrease or prevent the ecologic and socioeconomic services provided by made-man lakes (Scheffer, 1990).

The above-mentioned context should be highly considered in the State of Ceará wherein about 8,000 reservoirs provide water for socioeconomic establishments in a region under the influence of semi-arid tropical climate (Frischkorn et al., 2003, SRH, 2008; Martins et al., 2007). The water supply is based on small-farm dams to large reservoirs interconnected by a large-scale water diversion scheme involving almost all watersheds of the state. The Castanhão Reservoir is the largest impoundment of the State of Ceará and the major reservoir of the large-scale public water supply distribution system across the state. As many other reservoirs of the system, the five-year old Castanhão 
Reservoir with 6.7 billion $\mathrm{m}^{3}$ of storage capacity provides multiple water uses such as drinking water, irrigation, fishing, tourism, and cage aquaculture (SRH, 2008).

This recently flooded reservoir is probably still defining its ontogeny and the natural succession pathway; however it is already responsible for providing water for social and economic development. With increasing water availability the development of in-lake and watershed-based activities have been induced frequently without any control to assure preservation of this waterbody. Conflicts among multiple uses of the reservoirs will probably occur if a better understanding of the limnological conditions and the effects of pollution-prone activities will not be converted into effective management practices. Moreover, the semi-arid rainfall regime limits the freshwater inputs into the reservoir while outputs from dam are highly regulated according to management purposes. A simple water mass-balance budget indicates that reduced input and output define long water residence times of semi-arid reservoirs such as Castanhão which might enhance the threats of the nutrient over-enrichment (Molisani et al., 2007).

Thus, the aim of this work is to diagnose the limnological conditions of the Castanhão Reservoir through trophic state indices, phytoplankton assemblages and physical and chemical variables. This integrative analysis provides a first limnological characterization of this reservoir which will guide future management practices.

\section{Study area}

This study was carried out in the "açude" Castanhão Reservoir, the largest reservoir in the State of Ceará located at the border of middle and lower Jaguaribe River basin (Figure 1). The Jaguaribe River basin, with $72,645 \mathrm{~km}^{2}$, is the largest watershed in the State of Ceará. The watershed is under the influence of semi-arid climate, with average annual rainfall increasing from $450 \mathrm{~mm}$ in land to about $1,000 \mathrm{~mm}$ at the coast. Most of the rainfall (95\%) occurs during the rainy season (January to June) and is characterized by discrete precipitation pulses. During the dry period (July to December) rainfall is scarce. Potential evaporation amounts for about 2,100 mm (SRH, 2008). Rainfall regime and high evaporation are key environmental factors which induce the ephemeral conditions of the Jaguaribe River. During the rainy season the river flow averages $71 \mathrm{~m}^{3} \cdot \mathrm{s}^{-1}$ with maximum discharge reaching $3,485 \mathrm{~m}^{3} \cdot \mathrm{s}^{-1}$. In view of the ephemeral conditions, the runoff is absent during the dry periods (COGERH, 1997). The interannual rainfall variability is high, with annual rainfall variable coefficient of 0.36 (Gaiser et al., 2003) which is a major factor influencing the water management across the watershed.

The Castanhão Reservoir was completely flooded in 2004, covering a flooded area of $325 \mathrm{~km}^{2}$. Behind the $3.5 \mathrm{~km}$ wide and maximum $60 \mathrm{~m}$ height dam, 6.7 billions of $\mathrm{m}^{3}$ of water can be stored with optimal storage volume of 4.5 billons of $\mathrm{m}^{3}$. The reservoir is $48 \mathrm{~km}$ long and has a maximum depth of $60 \mathrm{~m}$. These characteristics classify the Castanhão as medium reservoir based on the flooded area and volume. The theoretical water residence time values of 4,000 and 7,295 days according to fluvial regime (Cogerh and Dnocs, 2003; Molisani et al., 2007) categorize it into the $\mathrm{C}$ class (residence time longer than one year) (Straškraba, 1999). The flooded area consists predominantly of crystalline bedrock and usually shallow soils with xerophytic woodland (Caatinga) as the dominant natural vegetation (Figueiredo, 1986).

The water stored in Castanhão Reservoir supplies 2.5 million inhabitants across the State of Ceará through a large-scale water diversion and irrigates about 40,000 ha of agricultural lands. In summary, dam operational rules are defined in relation to the water volume stored during the antecedent rainy season and meet demand withdrawal throughout the subsequent hydrological year (Cogerh and Dnocs, 2006). The multiple water uses also include tourism, fishing, and cage aquaculture. Cage fish farming have become the main activity of this reservoir with projected production of 50,000 ton/year when law limit of $1 \%$ of reservoir area will be used for cage aquaculture (Barcellos and Nunes, 2006).

\section{Material and Methods}

Water quality was monitored in six events during November/06, January, February, March, May and July/07 during the rainfall period. Water samples were taken in the inlet (riverine-lacustrine transition portion), middle and dam reservoir (Figure 1) at the subsurface and $-1 \mathrm{~m}$ from the bottom of water column using the Van Dorn bottle. Samples were stored in pre-cleaned bottles which were rinsed with the local water before filled. Physical-chemical variables (temperature, conductivity, $\mathrm{pH}$, Eh, and dissolved oxygen) were measured in situ using an YSI 556 Multi Probe System. Transparency was measured with a Secchi disk. $Z_{\text {max }}$ was expressed as the maximum water column depth. The euphotic 


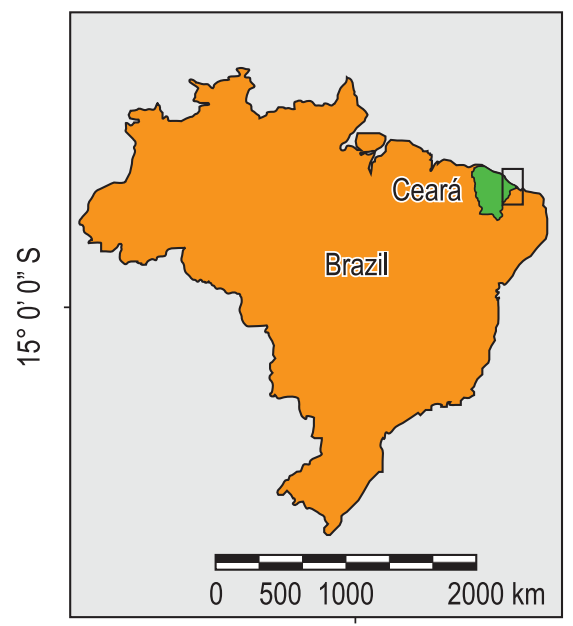

$55^{\circ} 0^{\prime} 0^{\prime \prime} \mathrm{W}$

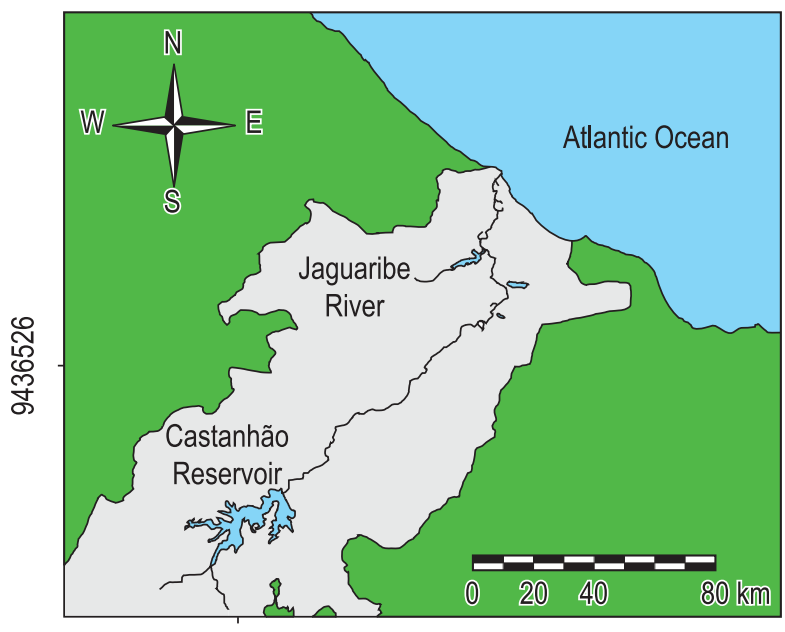

557890

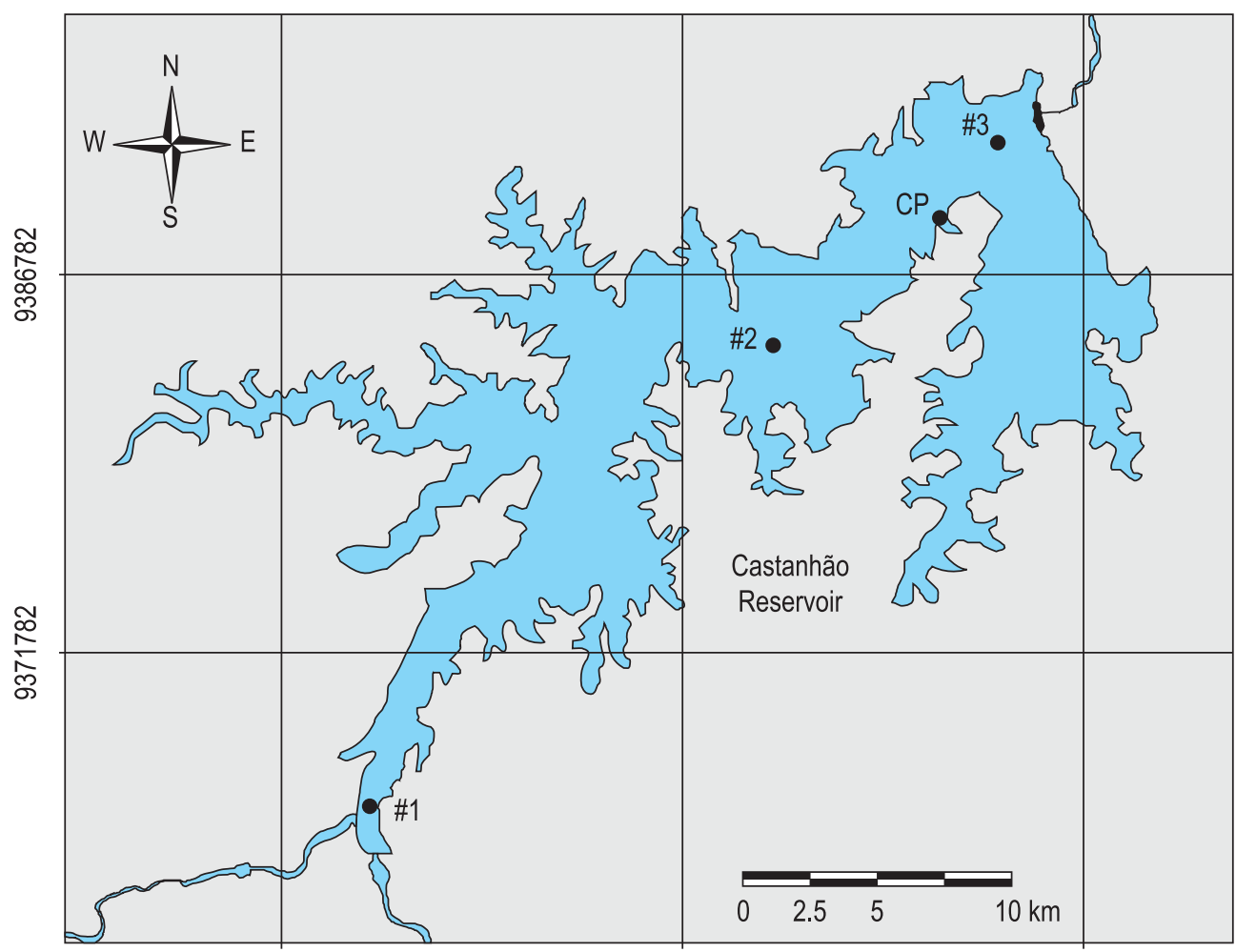

532178

547178

562178

Figure 1. Study area and sampling sites across the Castanhão Reservoir (\#1 inlet, \#2 middle and \#3 dam reservoir).

zone $\left(\mathrm{Z}_{\mathrm{eu}}\right)$ was estimated as 3 times the Secchi disk extinction depth (Cole, 1994).

Duplicate water samples were filtered through a $0.45 \mu \mathrm{m}$ membrane filter immediately after sampling and the filtrate kept frozen until analyzed within one day. Filters were used to obtain the suspended matter concentration in water samples through using the gravimetric procedure. Filtrate water samples were analyzed by spectrophotometric methods for ammonia $\left(\mathrm{NH}_{4}^{+}\right)$, soluble reactive phosporous (SRP) and dissolved silicate (D-Si) (Hubaux and Vox, 1970; APHA, 1998). Unfiltered samples were collected and kept frozen until spectrophotometric analysis for total nitrogen (TN) and total phosphorous (TP) (APHA, 1998). Water samples were also filtered through glass fiber filters and Chlorophyll-a determination was carried out after $90 \%$ acetone extraction by spectrophotometric analysis (APHA, 1998).

Phytoplankton samples for qualitative identification were collected at the water surface with $20 \mu \mathrm{m}$ mesh phytoplankton net and immediately preserved with $10 \%$ formalin solution. The main works used to algal identification were Anagnostidis 
and Komárek (1988), González (1996), Komárek and Anagnostidis (1989, 2000), Round et al. (1990), Tell and Conforti (1986) and Wehr and Sheath (2003). For quantitative analysis, water samples were taken from the surface and bottom with Van Dorn bottle and preserved immediately with $1 \%$ Lugol solution in opaque glass bottles. A sedimentation method was used for counting under an inverted microscope (Olympus CK2), according to the Utermöhl technique (magnification of $400 \times$ ). Phytoplankton were enumerated until at least 100 organisms (cell, colonies and filaments) per dominant species were recorded; giving a precision of $\pm 20 \%$ within $95 \%$ confidence limits (Wetzel and Likens, 2000). Relative abundance (\%) of classes and species were calculated based on the phytoplankton density (number of organisms. $\mathrm{L}^{-1}$ ). The phytoplankton was expressed as taxa descriptive, functional group, life form and frequency of occurrence for different sampling stations (inlet, middle, and dam reservoir). The functional group analysis followed the Reynolds' assemblages approach (Reynolds et al., 2002) which attributes a phytoplankton recognition nomenclature based upon the functional associations of species.

The trophic state of the reservoir was obtained by using the Modified Carlson Trophic Index (Toledo Jr. et al., 1983) and the index proposed by Lamparelli (2004). Both indices are composed by a set of Equations:

a) Trophic State Index (TSI) modified from Carlson (1977)

TSI (SD) $=10\left(6-\frac{0.64+\ln S \mathrm{D}}{\ln 2}\right)$

TSI $(\mathrm{Chl})=10\left(6-\frac{2.04-0.695 \ln \mathrm{Chl}}{\ln 2}\right)$

TSI $(\mathrm{TP})=10\left(6-\frac{\ln (80.32 / \mathrm{TP})}{\ln 2}\right)$

TSI (SRP) $=10\left(6-\frac{\ln (21.67 / \text { SRP })}{\ln 2}\right)$

where: SD = Secchi disk (m); Chl = Chlorophyll- $a$ $\left(\mu \mathrm{g} . \mathrm{L}^{-1}\right) ; \mathrm{TP}=$ Total phosphorous $\left(\mu \mathrm{g} . \mathrm{L}^{-1}\right)$; and $\mathrm{SRP}=$ Soluble reactive phosphorus $\left(\mu \mathrm{g} . \mathrm{L}^{-1}\right)$

The limits defined were:

- Oligotrophy: TSI < 44

- Mesotrophy: $44<$ TSI > 54

- Eutrophy: TSI > 54

b) Trophic State Index (TSI) proposed by Lamparelli (2004)
TSI $(\mathrm{SD})=10(6-((\operatorname{lnSD}) / \ln 2))$

TSI $(\mathrm{Chl})=10(6-(0.92-0.34(\ln \mathrm{Chl} / \ln 2))$

TSI $(\mathrm{TP})=10(6-(1.77-0.42(\ln \mathrm{TP})-\ln 2))$

where: SD = Secchi disk (m); Chl = Chlorophyll- $a$ $\left(\mu \mathrm{g} . \mathrm{L}^{-1}\right)$; and TP $=$ Total phosphorous $\left(\mu \mathrm{g} . \mathrm{L}^{-1}\right)$

The limits defined were:

- Ultra-Oligotrophy: $\leq 47$

- Oligotrophy: $47<$ TSI $\leq 52$

- Mesotrophy: $52<$ TSI $\leq 59$

- Eutrophy: $59<$ TSI $\leq 63$

- Supereutrophy: $63<\mathrm{TSI} \leq 67$

- Hypereutrophy: $>67$

The Spearman correlation matrices were obtained to determine the statistical relationship $(\mathrm{p}<0.05)$ between different limnological variables. The $t$-test was used to show statistically significant $(\mathrm{p}<0.05)$ spatial differences in the reservoir variables.

\section{Results}

\subsection{Physical, chemical and biological variables}

Table 1 shows the physical, chemical and biological variables relative to inlet, middle and dam reservoir (Figure 1). The riverine-lacustrine transition area has a fluvial physiography with lower depth $\left(Z_{\max }\right)$ and smaller channel width $(-40 \mathrm{~m})$ than typical lacustrine middle and dam sites. All analyzed variables were not significantly different between surface and bottom of the water column ( $p>0.05$ ). These lotic features related to fluvial influence might induce the statistically higher suspended matter, lower values of transparency and $\mathrm{Z}_{\mathrm{eu}}$ in the inlet reservoir than lacustrine middle and dam reservoir. The statistically higher suspended matter concentration attenuates the transparency of the water column of inlet reservoir which explains the lower primary phytoplankton productivity as represented by the statistically lower Chlorophyll- $a$ and total phytoplankton organism density than in middle and dam reservoir. Lower dissolved oxygen with one anoxia event in the bottom of water column in the inlet reservoir might be attributed to the addition of organic matter from river inflow and decomposition of macrophyte mats of Eichhornia crassipes Solms-Laubach which extensively colonize the lesser deep inlet waters. The concentration of $\mathrm{D}-\mathrm{Si}, \mathrm{SRP}$ and TN in this transitional zone were not statistically different of other sampling sites. Only TP concentration was statistically higher in the inlet than lacustrine areas. Ammonium concentrations 
Table 1. Mean (SD) and range of limnological variables measured in the inlet, middle and dam reservoir.

\begin{tabular}{|c|c|c|c|}
\hline & $\begin{array}{c}\# 1 \\
\text { (Inlet) }\end{array}$ & $\begin{array}{c}\# 2 \\
\text { (Middle) }\end{array}$ & $\begin{array}{c}\# 3 \\
(\text { Dam) } \\
\end{array}$ \\
\hline Mean depth (m) & 7.0 & 19 & 32 \\
\hline$Z_{\max }(m)$ & $7.0(1.0)$ & $17(4.0)$ & $33(7.0)$ \\
\hline $\mathrm{Z}_{\text {eu }}(\mathrm{m})$ & $3.4(1.1)$ & $5.6(0.9)$ & $6.0(1.0)$ \\
\hline \multirow[t]{2}{*}{ Secchi disk depth (m) } & $1.1(0.38)$ & $1.9(0.32)$ & $2.0(0.33)$ \\
\hline & $0.65-1.5$ & $1.6-2.3$ & $1.7-2.4$ \\
\hline \multirow{2}{*}{$\begin{array}{l}\text { Suspended matter } \\
\left(\mathrm{mg} \cdot \mathrm{L}^{-1}\right)\end{array}$} & $11(10)$ & $3.7(2.1)$ & $2.6(2.5)$ \\
\hline & $4.6-33$ & $0.72-8.4$ & $0.72-8.5$ \\
\hline \multirow[t]{2}{*}{ Temperature $\left({ }^{\circ} \mathrm{C}\right)$} & $29.2(0.7)$ & $28.9(1.0)$ & $28.6(1.2)$ \\
\hline & $28.3-30.4$ & $27.8-30.9$ & $27.3-30.8$ \\
\hline \multirow[t]{2}{*}{$\mathrm{pH}$} & $7.1(0.4)$ & $7.4(0.20)$ & $7.7(1.7)$ \\
\hline & 6.6.-7.8 & 7.2-7.7 & $7.2-8.1$ \\
\hline \multirow[t]{2}{*}{ Conductivity $\left(\mathrm{ms} \mathrm{cm}^{-1}\right)$} & $230(100)$ & $230(90)$ & $230(80)$ \\
\hline & $130-350$ & $130-280$ & $100-280$ \\
\hline \multirow{2}{*}{$\begin{array}{l}\text { Dissolved Oxygen } \\
\left(\mathrm{mg} \cdot \mathrm{L}^{-1}\right)\end{array}$} & $2.2(1.7)$ & $4.0(2.2)$ & $5.1(1.7)$ \\
\hline & $0-4.4$ & $1.2-6.5$ & $2.7-7.7$ \\
\hline \multirow[t]{2}{*}{ Dissolved Si (mg. $\left.\mathrm{L}^{-1}\right)$} & $5.7(0.82)$ & $5.1(1.3)$ & $5.2(1.5)$ \\
\hline & $4.1-6.9$ & $3.4-7.7$ & $4.0-8.6$ \\
\hline \multirow[t]{2}{*}{$\mathrm{NH}_{4}^{+}\left(\mu \mathrm{g} \cdot \mathrm{L}^{-1}\right)$} & $180(50)$ & $130(13)$ & $290(40)$ \\
\hline & $125-255$ & $110-150$ & $110-1,200$ \\
\hline \multirow[t]{2}{*}{$\operatorname{SRP}\left(\mu g \cdot L^{-1}\right)$} & $70(80)$ & $46(21)$ & $33(49)$ \\
\hline & $9.0-236$ & $23-76$ & $21-120$ \\
\hline \multirow[t]{2}{*}{$\mathrm{TN}\left(\mu \mathrm{g} \cdot \mathrm{L}^{-1}\right)$} & $920(300)$ & $850(410)$ & $790(450)$ \\
\hline & $600-1,543$ & $320-1,700$ & $190-1,800$ \\
\hline \multirow[t]{2}{*}{$\mathrm{TP}\left(\mu \mathrm{g} \cdot \mathrm{L}^{-1}\right)$} & $150(110)$ & $58(29)$ & $48(32)$ \\
\hline & $26-369$ & $24-84$ & $11-123$ \\
\hline \multirow[t]{2}{*}{$\mathrm{N}: \mathrm{P}$ (mol) } & $28(30)$ & $55(49)$ & $87(100)$ \\
\hline & $3.6-97$ & $12-164$ & $11-361$ \\
\hline \multirow[t]{2}{*}{ Chlorophyll-a ( $\left.\mu g . \mathrm{L}^{-1}\right)$} & $3.3(1.4)$ & $7.5(4.5)$ & $6.7(3.5)$ \\
\hline & $1.6-5.5$ & $0.71-15$ & $1.7-13$ \\
\hline \multirow{2}{*}{$\begin{array}{l}\text { Phytoplankton density } \\
\left(\times 10^{6} \text { organisms. } \mathrm{L}^{-1}\right)\end{array}$} & $3.5(4.2)$ & $44(22)$ & $24(26)$ \\
\hline & $0.11-12$ & $1.0-73$ & $0.34-68$ \\
\hline
\end{tabular}

were statistically higher than in middle portion and similar to dam reservoir.

The middle and dam reservoir have typical lacustrine physiographic with higher depth $\left(\mathrm{Z}_{\max }\right)$ and longer width channel $(-4 \mathrm{~km})$. In the middle reservoir, statistically higher values of total phytoplankton density $\left(58 \times 10^{6}\right.$ organisms. $\left.\mathrm{L}^{-1}\right)$ and lower concentration of TP were found in surface $\left(33 \mu \mathrm{g} . \mathrm{L}^{-1}\right)$ than in bottom waters $\left(30 \times 10^{6}\right.$ organisms. $\mathrm{L}^{-1}$ and $57 \mu \mathrm{g} . \mathrm{L}^{-1}$, respectively). For all other limnological variables statistical differences were not found between surface and bottom of the water column. The dam reservoir presented statistically higher values of total phytoplankton, temperature and dissolved oxygen in surface water $\left(46 \times 10^{6}\right.$ organisms. $\mathrm{L}^{-1}, 29.6^{\circ} \mathrm{C}$ and $6.0 \mathrm{mg} . \mathrm{L}^{-1}$, respectivelly) than the bottom of the water column $\left(6.0 \times 10^{6}\right.$ organisms. $\mathrm{L}^{-1}, 28.4^{\circ} \mathrm{C}$ and $4.8 \mathrm{mg} . \mathrm{L}^{-1}$, respectively). For all other variables statistical differences were not found in surface and bottom of the water column.

The distance from Jaguaribe River inlet $(-20 \mathrm{~km})$ reduces the suspended matter which increases the transparency and $Z_{\text {eu }}$ of the water column in the middle and dam reservoir. The higher light penetration into the water column induces phytoplankton productivity as revealed by the statistically higher values of Chlorophyll- $a$, total phytoplankton compared to inlet reservoir (Table 1). D-Si, SRP, $\mathrm{NH}_{4}^{+}$, TN, TP, Chlorophyll- $a$, total phytoplankton, and suspended matter were statistically similar for middle and dam sites.

\subsection{Phytoplankton assemblages}

Table 2 shows descriptor taxon, life form and frequency of occurrence in the different sampled reservoir portions. The phytoplankton flora was composed by 105 taxa including the Cyanophyceae (27\%), Chlorophyceae (25\%), Bacillariophyceae (13\%), Euglenophyceae (10\%), unidentified phytoflagellates $(<15 \mu \mathrm{m})(9 \%)$, Cryptophyceae (7\%), Zygnemaphyceae (5\%), Dinophyceae (2\%) and Xanthophyceae (2\%). Twenty-nine descriptive taxa were found during the sampling period and were composed by those with $>5 \%$ of the total phytoplankton density (organisms. $\mathrm{L}^{-1}$ ) in least one sample (Crosseti and Bicudo, 2008). According to the Reynolds' assemblages approach (Reynolds et al., 2002) and recent review from Padisák et al. (2009), 19 functional groups were identified during the study.

The inlet reservoir showed total phytoplankton density varying from $0.11 \times 10^{6}$ to $12 \times 10^{6}$ organisms. $\mathrm{L}^{-1}$. On average, no statistically differences were observed in phytoplankton density between surface $\left(4.5 \times 10^{6} \pm 4.6 \times 10^{6}\right.$ organisms. $\left.L^{-1}\right)$ and bottom waters $\left(2.6 \times 10^{6} \pm 3.7 \times 10^{6}\right.$ organisms. $\left.\mathrm{L}^{-1}\right)$. This reservoir portion had 18 descriptive taxa from at least 8 functional groups (Table 2) and 5 taxonomic classes (Table 2). Concerning relative abundance, Bacillariophyceae $(45 \pm 30 \%)$ accounted for the highest among all phytoplankton classes followed by Chlorophyceae (20 $\pm 15 \%)$, Cryptophyceae $(17 \pm 17 \%)$, Cyanophyceae $(8 \pm 10 \%)$, Phytoflagellates $(7 \pm 6 \%)$ and Euglenophyceae $(2 \pm 5 \%)$. The more abundant species belong to the functional groups $\mathrm{C}, \mathrm{X} 1, \mathrm{Y}$ and J, respectively (Figures 2 and 3). The most representative taxa of Bacillariophyceae were Aulacoseira distans var. distans and Cyclotella sp., representative of functional group C. Cryptomonas (functional 
Table 2. Descriptive taxa of phytoplankton, functional group, life form and frequency of occurrence in Castanhão Reservoir.

\begin{tabular}{|c|c|c|c|c|}
\hline Descriptor taxa & $\begin{array}{l}\text { Sampling } \\
\text { site }\end{array}$ & $\begin{array}{l}\text { Functional } \\
\text { group }{ }^{1} \\
\end{array}$ & $\begin{array}{l}\text { Life } \\
\text { form }{ }^{2}\end{array}$ & $\begin{array}{l}\text { Frequency of } \\
\text { occurrence }^{3} \\
\end{array}$ \\
\hline \multicolumn{5}{|l|}{ Cyanophyceae } \\
\hline Aphanocapsa sp. 2 & Dam & $\mathrm{K}$ & CNF & Rare \\
\hline Cyanotetras sp. & Middle & $?$ & CNF & Rare \\
\hline $\begin{array}{l}\text { Cylindrospermopsis raciborskii (Woloszýnska) } \\
\text { Seenayya \& Subba Raju }\end{array}$ & Middle/Dam & Sn & $\mathrm{Fi}$ & Constant \\
\hline $\begin{array}{l}\text { Planktolyngbya limnetica (Lemmerman) } \\
\text { Komárkova-Legnerová \& Cronberg }\end{array}$ & Middle/Dam & S1 & $\mathrm{Fi}$ & Constant \\
\hline Pseudanabaena galeata (Böcher) and P. catenata (Lauterborn) & Middle/Dam & MP & $\mathrm{Fi}$ & Constant \\
\hline Pseudanabaena limnetica (Lemmerman) Komárek & Middle/Dam & S1 & $\mathrm{Fi}$ & Constant \\
\hline Pseudanabaena cf. raphidioides (Geitler) Anagnostidis \& Komárek & Middle/Dam & $?$ & $\mathrm{Fi}$ & Constant \\
\hline Microcystis sp. & Middle & M & CNF & Rare \\
\hline Synechocystis aquatilis Sauvageau & Inlet/Middle/Dam & Lo & UNF & Constant \\
\hline Synechocystis sp. 2 & Inlet & $\mathrm{K}$ & UNF & Rare \\
\hline Romeria sp. & Inlet & $?$ & $\mathrm{Fi}$ & Rare \\
\hline \multicolumn{5}{|l|}{ Chlorophyceae } \\
\hline Botryococcus spp. & Dam & $\mathrm{F}$ & CNF & Rare \\
\hline Crucigenia sp. & Inlet/Dam & $\mathrm{J}$ & CNF & Common \\
\hline Monoraphidium minutum (Nägeli) Komárková-Legnerová & Inlet & $\mathrm{X} 1$ & UNF & Common \\
\hline Monoraphidium tortile (West \& West) Komárková-Legnerová & Inlet & $\mathrm{X} 1$ & UNF & Rare \\
\hline Pseudodidymocystis fina (Komárek) Hegewald \& Deason & Dam & $\mathrm{X} 1$ & CNF & Common \\
\hline Scenedesmus securiformis Playfair & Inlet/Dam & J & CNF & Common \\
\hline Scenedesmus graevenitzii (Bernard) Kofoid & Inlet & $\mathrm{J}$ & CNF & Rare \\
\hline Schroederia sp. & Inlet & $\mathrm{X} 1$ & UNF & Common \\
\hline \multicolumn{5}{|l|}{ Euglenophyceae } \\
\hline Trachelomonas sp. 1 & Inlet & W2 & UNF & Rare \\
\hline \multicolumn{5}{|l|}{ Cryptophyceae } \\
\hline Cryptomonas sp. 1 & Inlet & Y & UF & Common \\
\hline Cryptomonas sp. 2 & Inlet & Y & UF & Rare \\
\hline Cryptophyceae 1 & Inlet & Y & UF & Common \\
\hline \multicolumn{5}{|l|}{ Bacillariophyceae } \\
\hline Achnanthidium minutissimum (Kützing) Czarnecki & Middle/Dam & MP & UNF & Constant \\
\hline Aulacoseira distans (Ehrenberg) Simonsen var. distans & Inlet & C & CNF & Common \\
\hline Cyclotella sp. 1 & Inlet & C & UNF & Common \\
\hline Navicula sp. 2 & Inlet & MP & UNF & Common \\
\hline \multicolumn{5}{|l|}{ Phytoplagelates no identified ( $<15 \mu \mathrm{m}$ ) } \\
\hline Phytoflagellate 1 & Inlet/Dam & ? & UF & Common \\
\hline Phytoflagellate 2 & Inlet/Dam & ? & UF & Common \\
\hline
\end{tabular}

${ }^{1}$ Functional group: defined according to Reynolds et al. (2002). ${ }^{2}$ Life form: unicellular flagellates (UF), colonial flagellates (CF), unicellular non-flagellated (UNF), colonial non-flagellated (including coenobia) (CNF), and filaments $(\mathrm{Fi}) \cdot{ }^{3}$ Frequency of occurrence $(\%)$ : rare $(\mathrm{F} \leq 10 \%)$, common $(10 \%<\mathrm{F} \leq 50 \%)$ and constant $(\mathrm{F}>50 \%)$ based on the occurrence related to the total number of samples (? - unidentified taxa functional group).

group Y) were the main genera of Cryptophyceae while Monoraphidium spp. (X1), Schroederia sp. (X1), Crucigenia spp. (J) and Scenedesmus spp. (J) were the main taxa of Chlorophyceae. Synechocystis aquatilis (Lo) and Romeria sp. (?) were the main taxa of Cyanophyceae.

For the lacustrine middle and dam reservoir, the phytoplankton assemblages had density varying from $0.34 \times 10^{6}$ to $73 \times 10^{6}$ organisms. $\mathrm{L}^{-1}$. Statistically higher density was reported in surface $\left(53 \times 10^{6} \pm 18 \times 10^{6}\right.$ organisms. $\left.\mathrm{L}^{-1}\right)$ than bottom waters $\left(18 \times 10^{6} \pm 20 \times 10^{6}\right.$ organisms. $\left.\mathrm{L}^{-1}\right)$. In middle reservoir 9 descriptive taxa from at least 5 functional groups and 2 taxonomic classes were found. In dam reservoir was found 14 descriptive taxa were found from at least 8 functional groups 
and 3 taxonomic classes (Table 2). Cyanophyceae was the most abundant class in middle and dam reservoir ( $82 \pm 8 \%$ and $78 \pm 11 \%$, respectively). The main functional groups were S1, MP, Lo and Sn (Figure 2 and 3). The most representative Cyanophyceae were Cylindrospermopsis raciborskii (Sn), Planktolyngbya limnetica (S1), Pseudanabaena spp. (galeatalcatenata) (MP), Pseudanabaena limnetica (S1), Pseudanabaena cf. raphidioides (?) and Synechocystis aquatilis (Lo). Other classes

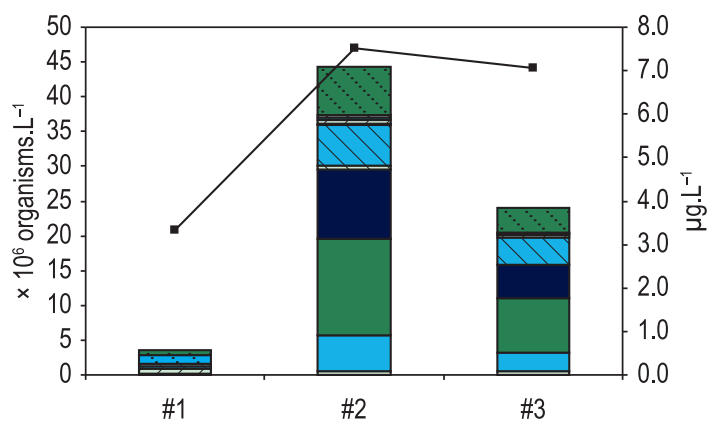

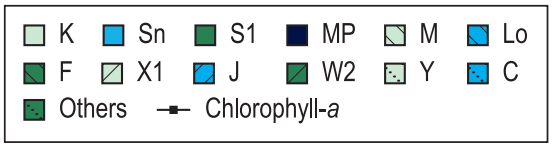

Figure 2. Total mean density (organisms. $\mathrm{L}^{-1}$ ) of the main phytoplankton functional groups and mean concentration of Clorophyll- $a$ for the three sampling sites across the Castanhão Reservoir during the sampling period.

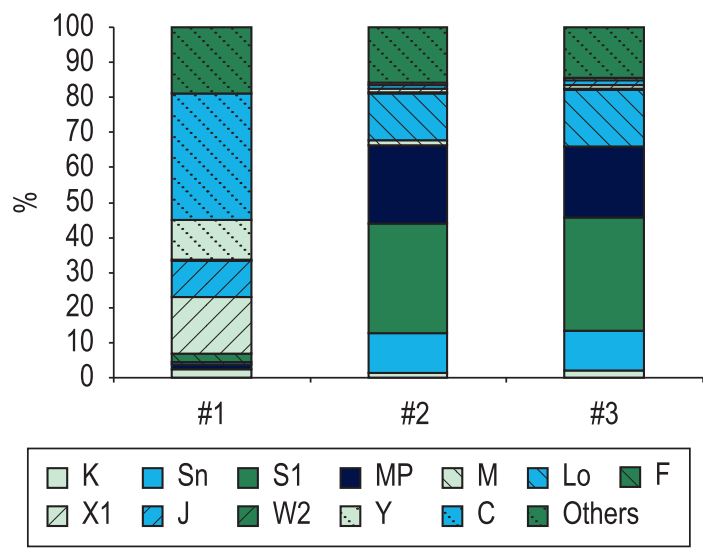

Figure 3. Mean relative abundance (\%) of the phytoplankton functional groups for the three sampling sites across the Castanhão Reservoir during the sampling period. were also important in middle and dam reservoir such as Bacillariophyceae (14 $\pm 7 \%$ and $14 \pm 9 \%$, respectively) and Chlorophyceae $(3 \pm 2 \%$ and $4 \pm 5 \%$, respectively), with predominant diatom such as Achnanthidium minutissimum (MP) and greens Botryococcus spp. (F), Crucigenia spp. (J), Pseudodidymocystis fina (X1) and Scenedesmus securiformis $(\mathrm{J})$.

\subsection{Trophic state evaluation}

An attempt to evaluate the trophic state of the Castanhão Reservoir was made by using the Modified Carlson Index and the index proposed by Lamparelli (2004) which set more accurate classification for the trophic status of tropical/ subtropical reservoirs. Table 3 shows the application of both indices to each reservoir portion and to the overall conditions of Castanhão Reservoir. Both indices classify the inlet reservoir as eutrophic and the middle and dam reservoir as mesotrophic. On average, the overall trophic state of the Castanhão Reservoir is the mesotrophic according to both indices.

\section{Discussion}

The trophic state evaluation indicated that the Castanhão Reservoir is actually a mesotrophic environment, although no inference could be made upon which position the reservoir is in the upsurge-depression curve (Kimmel and Groeger, 1986). The average time for the formation of a reservoir has been shown to vary from 4 to over 10 years. The Amazonian reservoirs, for example, are emphasized as taking more than 10 years to achieve stabilization as a result of the low decomposition rates of the submerged forest (Straškraba and Tundisi, 2000). The results from Figueiredo and Bianchini-Jr. (2008) indicated that after three years of impoundment flood, the Manso Reservoir was at the stabilization phase.

The physical and chemical conditions of the reservoir are important controlling factors of the phytoplankton assemblages. The more abundant assemblages in the inlet reservoir $(\mathrm{C}, \mathrm{X} 1, \mathrm{Y}$ and $\mathrm{J})$ are generally typical of mixed and/or turbid environments which might also have high nutrient content (Reynolds et al., 2002; Padisák et al.,

Table 3. Classification of trophic state of inlet (\#1), middle (\#2), and dam (\#3) reservoir and as a mean for the whole Castanhão Reservoir.

\begin{tabular}{lccccc}
\hline & Inlet & Middle & Dam & Castanhão & Reservoir trophic state \\
\hline Modified Carlson Index & 56 & 53 & 50 & 53 & Mesotrophy \\
Lamparelli (2004) & 60 & 57 & 56 & 58 & Mesotrophy \\
\hline
\end{tabular}


2009). Despite the higher N:P ratio, the higher TP concentrations and the statistically inverse Spearman correlation between total phytoplankton density and SRP $(r=-0.58 ; \mathrm{P}<0.05)$ suggest that phosphorous is not a limiting factor for phytoplankton growth, at least in the inlet reservoir (Table 4). The positive correlation between the total phytoplankton density and transparency $(\mathrm{r}=0.48, \mathrm{P}<0.05)$ (Table 4) and the higher concentration of suspended matter, lower transparency and $\mathrm{Z}_{\mathrm{eu}}$ indicate light as a limiting factor for inlet limnological conditions. Thus, some of the most representative algae species develop adaptations to survive under the low transparency conditions reported in inlet waters. The data from Bovo-Scomparin and Train (2008) reported the dominance of Aulacoseira distans (C) and Cryptomonas spp. (Y) in the floodplain Ventura lagoon (Brazil) under high inorganic dissolved nitrogen concentrations, especially ammonium, $\mathrm{N}: \mathrm{P}$ ratios, turbidity and low light availability, soluble reactive phosphorous and mixture of the water column. According to Kruk et al. (2002), other species found in the inlet area such as Monoraphidium minutum and $M$. tortile (both X1) also benefit from high TP, SRP and $\mathrm{NH}_{4}$ concentrations.

The lacustrine middle and dam reservoir have higher density of total phytoplankton than the inlet reservoir based on lower suspended matter and higher Secchi transparency. Among the more abundant functional groups found in this reservoir portion, the functional groups $\mathrm{Sn}, \mathrm{S} 1$ and MP should be highlighted as adapted to high turbidity and well-mixed waters (Reynolds et al., 2002; Padisák et al., 2009). Despite these groups indicate a well-mixed water column, this condition might be restrict to surface waters in view of significant differences $(\mathrm{p}<0.05)$ found between surface and bottom waters for variables as temperature, dissolved oxygen, TP, and total phytoplankton density. The higher relative abundance of Cyanophyceae whose species have gas vacuoles that decrease the sink of organisms (Padisák, 1997; O’Farrell et al., 2007) also indicate more stable water column conditions compared to inlet waters. Additionally, physicalchemical conditions of lacustrine middle and dam reservoir sites are also important controlling factors of phytoplankton assemblages. Total phytoplankton has statistical inverse correlation with D-Si $(\mathrm{r}=-0.38)$ and $\operatorname{SRP}(\mathrm{r}=-0.58)$ (Table 4) suggesting that nutrient uptake by phytoplankton assemblages for metabolic purposes (Esteves, 1998; Reynolds, 1984) might be an important controlling factor of dissolved nutrient distribution across lacustrine reservoir portion.

Among the Cyanophycea species, the Cylindrospermopsis raciborskii is a representative taxa which is also reported in many reservoirs, including those eutrophic, located at semi-arid Brazilian Northeastern (Bouvy et al., 2000; Huszar et al., 2000; Chellappa and Costa, 2003) as well as in the State of Ceará (Barroso, 2006; Oliveira, 2006) suggesting adaptation of $C$. raciborskii to ecological conditions of aquatic environments under the influence of semi-arid climate. The ecological importance of $C$. raciborskii relies on dense bloom formation, potential toxicity and toxin production with serious public health threats (Padisák, 1997; FUNASA/MS-Brasil, 2003; Chellappa et al., 2008).

Other Cyanophyceae species such as Pl. limnetica (S1), Ps. galeatalcatenata (MP), Ps. limnetica (S1),

Table 4. Spearmam rank order correlation of limnological variables of Castanhão Reservoir. Marked correlations are significant at $\mathrm{p}<0.05000$.

\begin{tabular}{|c|c|c|c|c|c|c|c|c|c|c|c|c|}
\hline & $\mathrm{D}-\mathrm{Si}$ & SRP & TP & $\mathrm{NH}_{4}^{+}$ & TN & Chl-a & TSS & $\begin{array}{l}\text { Phyto. } \\
\text { density }\end{array}$ & Cond. & $\mathrm{O}_{2}$ & $\mathrm{pH}$ & Transp \\
\hline D-Si & 1.000 & - & - & - & - & - & - & - & - & - & - & - \\
\hline SRP & -0.061 & 1.000 & - & - & - & - & - & - & - & - & - & - \\
\hline TP & -0.0021 & 0.564 & 1.000 & - & - & - & - & - & - & - & - & - \\
\hline $\mathrm{NH}_{4}^{+}$ & 0.057 & -0.022 & -0.053 & 1.000 & - & - & - & - & - & - & - & - \\
\hline TN & 0.017 & 0.062 & 0.249 & -0.042 & 1.000 & - & - & - & - & - & - & - \\
\hline Chl-a & -0.555 & -0.339 & -0.279 & 0.299 & -0.136 & 1.000 & - & - & - & - & - & - \\
\hline TSS & -0.249 & 0.285 & 0.390 & 0.213 & 0.050 & 0.337 & 1.000 & - & - & - & - & - \\
\hline $\begin{array}{l}\text { Phytoplankton } \\
\text { density }\end{array}$ & -0.382 & -0.577 & -0.396 & -0.113 & 0.048 & 0.585 & -0.083 & 1.000 & - & - & - & - \\
\hline Conductivity & 0.218 & 0.029 & 0.040 & 0.175 & -0.506 & -0.143 & 0.228 & -0.326 & 1.000 & - & - & - \\
\hline $\mathrm{O}_{2}$ & -0.465 & -0.527 & -0.448 & 0.135 & 0.039 & 0.572 & 0.169 & 0.445 & 0.247 & 1.000 & - & - \\
\hline ph & 0.134 & -0.261 & -0.458 & -0.092 & -0.004 & -0.038 & -0.383 & 0.176 & -0.535 & 0.129 & 1.000 & - \\
\hline Transparency & -0.294 & -0.417 & -0.656 & -0.001 & -0.140 & 0.135 & -0.608 & 0.482 & 0.093 & 0.744 & -0.091 & 1.000 \\
\hline
\end{tabular}


Ps. cf. raphidioides (?) and S. aquatilis (Lo) were also found in Castanhão Reservoir. According to Marinho and Azevedo (2007) nitrogen availability might be a key factor of non-nitrogen-fixing Cyanophyceae dominance. Thus, Cyanophyceae species from lacustrine portion of the Castanhão reservoir are favoured by ammonium concentration based on positive correlation between this nutrient and Chlorophyll- $a(\mathrm{r}=0.30 ; \mathrm{P}<0.05)$ (Table 4). At the same time, low sink rates, low susceptibility of grazing and adaption to low light intensity are also important features related to high representative of Cyanophyceae in lacustrine freshwaters (Padisák, 1997; Nixdorf et al., 2003; Salmaso, 2003; Padisák et al., 2009). Additionally, species such as Pl. limnetica, Ps. catenata, Ps. galeata, , Ps. limnetica and $S$. aquatilis are widely found in mesotropicl eutrophic aquatic environments (Adler et al., 2000; Salmaso, 2002; Villena and Romo, 2007; Soares et al., 2007) justifying the abundance of these species in the Castanhão Reservoir.

Also in the lacustrine portion of the reservoir, the presence of diatom Achnanthidium minutissimum and not $A$. distans var. distans, which were reported in the inlet reservoir, might also be associated to higher water column stability. As Achnanthidium minutissimum individuals are smaller than $A$. distans var. distans, we might suppose that lower weight favors flotation of $A$. minutissimum in less turbulent waters. The $A$. minutissimum is usually reported in aquatic environments ranging from oligotrophic to eutrophic conditions (Potapova and Charles, 2007).

In summary, after five years of complete flooding the Castanhão Reservoir is a mesotrophic environment. However, both in-lake and watershedbased activities (eg. urbanization, agriculture, husbandry, aquaculture, all without proper waste treatment) might become prone-pollution sources to the reservoir and induce or accelerate eutrophic conditions considering its mesotrophic state. The results suggested that phytoplankton assemblages might be influenced by nutrient content and light availability to the water column. Thus, changes on nutrient inputs might induce modification on quantitative and qualitative algae composition inducing for example the algae bloom of potential toxic species Cylindrospermopsis raciborskii and other symptoms of euthrophycation as depletion of dissolved oxygen which was already found in the Castanhão Reservoir.

\section{Acknowledgements}

This work was supported by DCR program from National Research Council of Brazil (CNPq) and Fundação Cearense de Apoio ao Desenvolvimento Científico e Tecnológico (FUNCAP) (1514-14 CV. 016/2005, Proc. No 222/04). FUNCAP/CNPq/ UFC also provides PIBIC grants to undergraduate students Thiago M. do Monte and George H. Vasconcellos. We are grateful to the Departamento Nacional de Obras Contra a Seca (DNOCS/Ceará) to provide logistical help during samplying survey in the Castanhão reservoir.

\section{References}

ADLER, M., GERVAIS, F. and SIEDEL, U., 2000. Phytoplankton species composition in the chemocline of mesotrophic lakes. Archiv fur Hydrobiologie, vol. 55, p. 513-530.

American Public Health Association - APHA, 1998. Standard methods for examination of water and wastewater. $20 \mathrm{ed}$. Washington.

ANAGNOSTIDIS, K. and KOMÁREK, J., 1988. Modern approach to the classification system of cyanophytes. 3 - oscillatoriales. Archiv fur Hydrobiologie, vol. 50-53, 327-472.

BARCELLOS, CV. and NUNES, TF., 2006. Tilápia: produção, mercado, perspectivas para o Estado do Ceará. Ceará: Instituto Agropolos do Ceará. 29 p.

BARROSO, HS., 2006. Variação temporal e espacial do fitoplâncton em uma lagoa costeira no litoral leste do Ceará, Lagoa do Batoque. Fortaleza: Universidade Federal do Ceará. [Monografia]

BOUVY, M., FALCÁO, D., MARINHO, M., PAGANO, M. and MOURA, A., 2000. Occurrence of Cylindrospermopsis (Cyanobacteria) in 39 brazilian tropical reservoirs during the 1998 drought. Aquatic Microbial Ecology, vol. 23, p. 13-27.

BOVO-SCOMPARIN, VM. and TRAIN, S., 2008. Long-term variability of the phytoplankton community in an isolated floodplain lake of the Ivinhema River State Park, Brazil. Hydrobiologia, vol. 610, no. 1, p. 331-344.

BRASIL. Ministério da Saúde. Fundação Nacional de Saúde - FUNASA, 2003. Cianobactérias tóxicas na água para consumo humano na saúde pública $e$ processos de remoção em água para consumo humano. Brasília. 56 p.

CARLSON, RE., 1977. A trophic state index for lakes. Limnology and oceanography, vol. 22, no. 2, p. 361-369.

CHELlAPPA, NT. and COSTA, MAM., 2003. Dominant and co-existing species of Cyanobacteria from a euthropicated reservoir of Rio Grande do 
Norte State Brazil. Acta Oecologia, vol. 24, no. 1, p. S3-S10.

CHELLAPPA, NT., CHELLAPPA, SL. and CHELlaPPA, S., 2008. Harmful Phytoplankton blooms and fish mortality in a eutrophicated reservoir of Northeast Brazil. Brazilian Archives of Biology and Technology, vol. 51, no. 4, p. 833-841.

COLE, GA., 1994. Textbook of limnology. Illinois: Waveland Press.

Companhia de Gerenciamento dos Recursos Hídricos COGERH, 1997. Plano de gerenciamento das águas da Bacia do Rio Jaguaribe: estudos da base de hidrologia. Ceará. 166 p.

Companhia de Gerenciamento dos Recursos Hídricos COGERH and Departamento Nacional de Obras Contras as Secas - DNOCS, 2003. Anuário do monitoramento quantitativo dos principais açudes do Estado do Ceará, Açude Castanhão. Alto Santo.

Companhia de Gerenciamento dos Recursos Hídricos COGERH and Departamento Nacional de Obras Contras as Secas - DNOCS, 2006. In XII Seminário de alocação das águas dos vales do Jaguaribe e Banabuiú. Local de publicação.

CROSSETTI, LO. and BICUDO, CEM., 2008 Phytoplankton as a monitoring tool in a tropical urban shallow reservoir (Garças Pond): the assemblage index application. Hydrobiologia, vol. 610, no. 1, p. 161-173.

ESTEVES, FA., 1998. Fundamentos de limnologia. Rio de Janeiro: Interciência. 602 p.

FIGUEIREDO, MA., 1986. Vegetação. In Superintendência do Desenvolvimento do Estado do Ceará - SUDEC. Atlas do Ceará. Fortaleza. p. 24-25.

FIGUEREDO, DM. and BIANCHINI Jr., I., 2008. Limnological patterns of the filling and stabilization phases in the Manso multiple-use reservoir (MT). Acta Limnologica Brasiliensia, vol. 20, no. 4, p. 277-290.

FRISCHKORN, H., ARAÚJO, JC. and SANTIAGO, MMF., 2003. Water resources of Ceará and Piauí. In GAISER, T., KROL, MS., FRISCHKORN, H. and ARAÚJO, JC. (Eds.). Global change and regional impacts: water availability and vulnerability of ecosystems and society in the semi-arid Northeast of Brazil. Berlin: Springer-Verlag. p. 87-94.

GAISER, T., KROL, MS., FRISCHKORN, H. and ARAÚJO, JC., 2003. Global change and regional impacts: water availability and vulnerability of ecosystems and society in the semi-arid Northeast of Brazil. Berlin: Springer-Verlag. 428 p.

GONZÁLEZ, AG., 1996. Las Chlorococcales dulciacuicolas de Cuba. Berlin: Gebrüder Borntraeger. 269 p.

HALL, RI., LEAVITT, PR., DIXIT, AS., QUINLAN, R. and SMOL, JP., 1999. Limnological succession in reservoirs: a paleolimnological comparison of two methods of reservoir formation. Canadian journal of fisheries and aquatic sciences, vol. 56, no. 6, p. 1109-1121.

HUBAUX, A. and VOX, G., 1970. Decision and detection limits for linear calibration curves. Analytical Chemistry, vol. 42, no. 8, p. 849-855.

HUSZAR, VLM., SILVA, LHS., DOMINGOS, P., MARINHO, M. and SANT'ANNA, CL., 2000. Cyanoprokaryote assemblages in eight productive tropical brazilian waters. Hydrobiologia, vol. 424, no. 1-3, p. 67-77.

KIMMEL, BL. and GROEGER, AW., 1986. Limnological and ecological changes associated with reservoir aging. In HALL, GE. and van den AVYLE, MJ. (Eds.). Reservoir fisheries management: strategies for the 80's. Bethesda: Reservoir Committee. p. 103-109.

KOMÁREK, J. and ANAGNOSTIDIS, K., 2000. Cyanoprokaryota. 1. Teil: Chroococcales. In ETTL, H., GÄRTNER, G., HEYNIG, H. and MOLLENHAUER, D. (Eds.). Sübwasserflora von Mitteleuropa. Stuttgart: Gustav Fischer. 548 p.

KOMÁREK, J. and ANAGNOSTIDIS, K., 1989. Modern approach to the classification system of cyanophytes. 4 - Nostocales. Archiv fur Hydrobiologie, vol. 56, p. 247-345.

KRUK, C., MAZZEO, N., LACEROT, G. and REYNOLDS, CS., 2002. Classification schemes of phytoplankton: selecting an ecological approach for the analysis of species temporal replacement. Journal of Plankton Research, vol. 24, no. 9, p. 901-912.

LAMPARELLI, MC., 2004. Graus de trofia em corpos d'água do Estado de São Paulo: avaliação dos métodos de monitoramento. São Paulo: Universidade de São Paulo. [Tese de Doutorado]

MARINHO, MM. and AZEVEDO SMF., 2007. Influence of N/P ratio on competitive abilities for nitrogen and phosphorus by Microcystis aeruginosa and Aulacoseira distans. Aquatic Ecology, vol. 41, p. 525-533.

MARTINS, ESPR., MENESCAL, RA., SCHERERWAREN, M., CARVALHO, MSBS., MELLO, MS., PERINI, DS. and OLIVEIRA, FAJ., 2007. Utilização de imagens CBERS para mapeamento dos espelhos d'água do Brasil. In Anais 13 Simpósio Brasileiro de Sensoriamento Remoto, Abril 21-26. Florianópolis: INPE, 2007. p. 969-976.

MOLISANI, MM., LEITE, LJA. and FARIAS EGG., 2007. Tilapicultura cearense: uma reflexão sobre a capacidade de suporte dos reservatórios. Panorama da Aquicultura, vol. 17, p. 32-33.

NIXDORF, B., MISCHKE, U., and RÜCKER, J., 2003. Phytoplankton assemblages and steady state in deep and shallow eutrophic lakes: an approach to differentiate the habitat properties of Oscillatoriales. Hydrobiologia, vol. 502, no. 1-3, p. 111-121. 
O'FARRELL, I., PINTO, PT. and IZAGUIRRE, I., 2007. Phytoplankton morphological response to the underwater light conditions in a vegetated wetland. Hydrobiologia, vol. 578, no. 1, p. 65-77.

OLIVEIRA, EC., 2006. Aspectos limnológicos e sanitários de uma lagoa costeira no litoral leste do Ceará: lagoa do Batoque. São Carlos: Universidade Federal de São Carlos. [Dissertação de Mestrado]

PADISÁK, J., 1997. Cylindrospermopsis raciborskii (Woloszynska) Seenayya et Subba Raju, an expanding, highly adaptive cyanobaterium: worldwide distribuition and review of its ecology. Archiv fur Hydrobiology, no. 107, p. 563-593.

PADISÁK, J., CROSSETTI, LO. and NASELIFLORES, L., 2009. Use and misuse in the application of the phytoplaknton functional classification: a critical review with updates. Hydrobiologia, vol. 621, p. 1-19.

POTAPOVA, M. and CHARLES, DF., 2007. Diatom metrics for monitoring eutrophication in rivers of the United States. Ecology Indicators, vol. 7, no. 1, p. $48-70$.

REYNOLDS, CS., 1984. The ecology of freshwater phytoplankton. Cambridge: Cambridge University Press. 384 p.

REYNOLDS, CS., HUSZAR, V., KRUK, C., NASELLI-FLORES, L. and MELO, S., 2002. Towards a functional classification of the freshwater phytoplankton. Journal of plankton research, vol. 24, no. 5, p. 417-428.

ROUND, FE., CRAWFORD, RM. and MANN, DG., 1990. The Diatoms Biology and Morphology of the Genera. Cambridge: Cambridge University Press. $747 \mathrm{p}$.

SALMASO, N., 2002. Ecological patterns of phytoplankton assemblages in Lake Garda: seasonal, spatial and historical features. Journal Limnology, vol. 61 , no. 1 , p. 95-115.

SALMASO, N., 2003. Life strategies, dominance patterns and mechanisms promoting species coexistence in phytoplankton communities along complex environmental gradients. Hydrobiologia, vol. 502, no. $1-3$, p. 13-36.
SCHEFFER, M., 1990. Multiplicity of stable states in freshwater systems. Hydrobiologia, vol. 200-201, no.1, p. 475-486.

Secretaria de Recursos Hídricos - SRH, 2008. Programa de açudes estratégicos. Ceará. Available from: www. srh.ce.gov.br.

SOARES, MCS., HUSZAR, VLM. and ROLAND, F., 2007. Phytoplankton dynamics in two tropical rivers with different degrees of human impact (Southeast Brazil). River Research And Applications, vol. 23, no.7, p. 698-714.

STRAŠKRABA, M. and TUNDISI, JG., 2000. Diretrizes para o gerenciamento de lagos: gerenciamento da qualidade da água de represas. São Carlos: CNPq. $258 \mathrm{p}$.

STRAŠKRABA, M., 1999. Retention time as a key variable of reservoir limnology. In TUNDISI, JG. and STRAŠKRABA, M. (Eds.). Theoretical reservoir ecology and its applications. São Carlos: Brazilian Academy of Sciences. p. 385-410.

TELL, G. and CONFORT, V., 1986. Euglenophyta pigmentadas de la Argentina. Berlin: Cramer. 301 p.

TOLEDO Jr., AP., TALARICO, M., CHINEZ, SJ. and AGUDO, EG., 1983. A aplicação de modelos simplificados para a avaliaçáo e processo de eutrofização em lagos e reservatórios tropicais. In Anais do 12 Congresso Brasileiro de Engenharia Sanitária e Ambiental. Rio de Janeiro: Associação Brasileira de Engenharia Sanitária e Ambiental. p. 1.34 .

VILLENA, MJ. and ROMO, S., 2007. Effects of Nutrients, Fish, Charophytes and Algal Sediment Recruitment on the Phytoplankton Ecology of a Shallow Lake. International review of hydrobiology, vol. 92, no. 6, p. 626-639.

WEHR, JD. and SHEATH, RG., 2003. Freshwater Algae of North America: ecology and classification. New York: Academic Press. 918 p.

WETZEL, RG. and LIKENS, GE., 2000. Limnological analyses. 3 ed. New York: Springer-Verlag. 429 p.

Received: 08 October 2009 Accepted: 05 March 2010 